\title{
Comparative Analysis of High Voltage Battery Pack Cells for Electric Vehicle
}

\author{
Khaled Sehil \\ Department of Electronic \\ and Computer Engineering, \\ Brunel University \\ London, UK \\ khaled.sehil@edwardsvacuu \\ m.com
}

\author{
Mohamed Darwish \\ Department of Electronic and \\ Computer Engineering, \\ Brunel University \\ London, UK \\ mohamed.darwish@Brunel.ac.uk
}

\author{
Christos. C Marouchos \\ Department of Electrical \\ Engineering, \\ Cyprus University of \\ Technology \\ Limassol, Cyprus \\ christos.marouchos@cut.ac.cy
}

\author{
William C. Jeans \\ Department of Electronic and \\ Computer Engineering, \\ Brunel University \\ London, UK \\ billyjeans@hotmail.co.uk
}

\begin{abstract}
Improving the lifetime of electric vehicles is inevitably required for the widely commercializing. This paper attributes the lithium battery cell (LIB) as an electrical energy storage unit for electrically powered motor vehicles. A comparative analysis for 5 lithium cells from different manufacturers has been investigated and analysed. The comparisons have been prepared for Start Voltage, End Voltage, Current, and the use of active cooling under different test conditions, that includes charging and discharging, with and without cell cooling system.
\end{abstract}

Index Terms - Lithium battery, Cell, Energy Storage

\section{INTRODUCTION}

The efficiency of the "tank to wheels" in the electrical vehicles (Ev's) compared to the internal combustion engine vehicles (which is approximately three times higher [1]) promoted the argued vision to consider electrical vehicles as the future of personal and commercial transport. Energy storage cells afford huge reductions vehicle emissions and high overall efficiencies of $70 \%$ in comparison to $35 \%$ typically found in traditional internal combustion engines [2]. Further, electric vehicle batteries are required to handle high power outputs (up to a hundred $\mathrm{kW}$ ), have a high-energy capacities (up to tens of $\mathrm{kWh}$ ), must have relatively low weight and footprint (for installation into spaces) and must be at an affordable price for the intended consumer. Extensive research effort and investment have been contributed to advanced battery technologies, which are suitable for electrical vehicles all over the world.

This paper presents comparative study between lithium battery cells from different manufacturer used in high voltage battery pack for an electric racing car. The battery pack main specifications are:

- $\quad 400 \mathrm{VCD}$, maximum voltage due to motor controller has an upper voltage limit of 400 VDC.

- Maximum Discharge Current 200A,

- Battery Capacity $7 \mathrm{~kW}$
- $\quad$ Power output $80 \mathrm{~kW}$.

These specifications have been chosen to be inside the standard of the Tractive system energy storage [8]

\section{BATTERY TECHNOLOGY IN ELECTRICAL VEHICLE}

The current two major battery technologies used in EVs are Nickel Metal Hydride (NiMH) and Lithium ion (Li-ion), $\mathrm{NiMH}$ batteries have cell voltage range between $0.9 \mathrm{~V}-1.6 \mathrm{~V}$, perform well at low temperatures (in the range from $-20^{\circ} \mathrm{C}$ to$40^{\circ} \mathrm{C}$ ), Power transfer efficiencies (typical in the range of 72 $78 \%$ ), gravimetric energy densities $(50-70 \mathrm{Wh} / \mathrm{kg})$, life span 500 cycle at $100 \%$ depth of discharge), however, they suffer from memory effects and lose additional energy owing to selfdischarge standby [6,7].

While the Lithium batteries, have high cell voltage levels of up to 3.7 nominal Volts, high gravimetric energy densities (100$150 \mathrm{Wh} / \mathrm{kg}$ ) and high-power transfer efficiencies (typically in the range of $95 \%$ to $98 \%$ ), life span 3000 cycle at $80 \%$ depth of discharge). Discharge time can vary from a few seconds to several weeks and they have very quick time responses [7]. Fig.1, illustrates the volumetric and gravimetric energy densities based on bare battery cells technology.

Consider the advantages of the Lithium battery mentioned above, motivated the study in this paper which is based on Lithium battery technology.

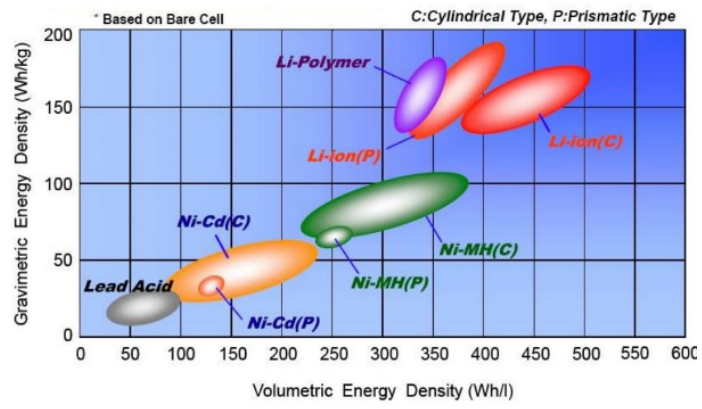

Fig. 1: Energy comparison between battery Cells 


\section{A. Cell Selection:}

Based on the required parameters, five most promising Lithium battery cells are selected by the the battery calculator design software (As shown in Table 1). The selection is calculated by comparing 24 different cells from various manufactures with different parameters including cell size, discharge rates, the chemistry and the number of cells required to reach total traction voltage, cell voltage, battery capacity and the energy density of the cell. Those batteries were thoroughly tested both electrically and thermally.

TABLE 1. THE FIVE MOST APPROPIRATE LI-ION CELLS SELECTED

\begin{tabular}{|c|c|c|c|c|c|c|}
\hline & & & & \multicolumn{3}{|c|}{ Discharge (A) } \\
\hline $\begin{array}{c}\text { Cell } \\
\text { Name }\end{array}$ & $\mathrm{mAh}$ & $\begin{array}{c}\text { Chemis } \\
\text { try }\end{array}$ & $\begin{array}{l}\text { Module } \\
\text { required } \\
\text { in } \\
\text { parallel }\end{array}$ & Pulse & $\begin{array}{c}\text { Contin } \\
\text { uous }\end{array}$ & $\begin{array}{l}\text { Peak } \\
\text { pack }\end{array}$ \\
\hline $\begin{array}{c}\text { Sony } \\
\text { VTC6 }\end{array}$ & 3000 & Li-Ion & 6 & 30 & 15 & 180 \\
\hline $\begin{array}{c}\text { Sony } \\
\text { VTC5 }\end{array}$ & 2500 & Li-Ion & 7 & 30 & 20 & 210 \\
\hline $\begin{array}{c}\text { LG DB } \\
18650 \\
\text { HG2 }\end{array}$ & 3000 & Li-Ion & 6 & 20 & 20 & 120 \\
\hline $\begin{array}{c}\text { Samsung } \\
18650 \\
30 Q\end{array}$ & 3000 & Li-Ion & 6 & 15 & 15 & 90 \\
\hline $\begin{array}{c}\text { Samsung } \\
18650 \\
25 \mathrm{R}\end{array}$ & 2500 & Li-Ion & 6 & 20 & 20 & 120 \\
\hline
\end{tabular}

\section{COMPARATIVE ANALYSIS OF LI-ION BATTERY CELL}

To achieve fairness and most accurate results from the comparison, all the battery cells are brand new, stored under the same conditions and with no mechanical damage. Each of the cells is tested at least four times under different test conditions, the discharge test conditions are detailed in Table 2. Current discharge is selected as $15 \mathrm{~A}$ and $30 \mathrm{~A}$, which are the maximum discharge for these cells and its halves.

TABLE 2. SINGLE CELL TEST CONDITION

\begin{tabular}{|l|l|l|l|l|}
\hline \multicolumn{1}{|c|}{ Test } & \multicolumn{1}{c|}{$\mathbf{1}$} & \multicolumn{1}{c|}{$\mathbf{2}$} & \multicolumn{1}{c|}{$\mathbf{3}$} & \multicolumn{1}{c|}{$\mathbf{4}$} \\
\hline Start Voltage (V) & 4.00 & 4.00 & 4.00 & 4.00 \\
\hline End Voltage (V) & 2.50 & 2.50 & 2.50 & 2.50 \\
\hline Current (A) & 15 & 30 & 15 & 30 \\
\hline Use of active cooling & No & No & Yes & Yes \\
\hline
\end{tabular}

While adhering to these strict test procedures, the cell temperature(s) were monitored by a thermocouple which is attached in the center of the casing of the cell, the other end connected to a channel in TC- 08 data logger.

Automatically, and specific safety conditions are set for aborting the testing if reached.

These conditions are:

a) A cell temperature exceeding the maximum temperature as stipulated in the cell Material Safety Data Sheet (MSDS), b) If the maximum current specified in the MSDS was exceeded or

c) If the cell reaches the lower voltage limit specified in the MSDS.

The type of the cell discharge load was a programmable resistive load

\section{RESULTS AND DISCUSSION}

\section{A. Test1: Continuous 15A discharge with No active cooling}

The Output voltage and internal temperature of the cell was recorded during the test.

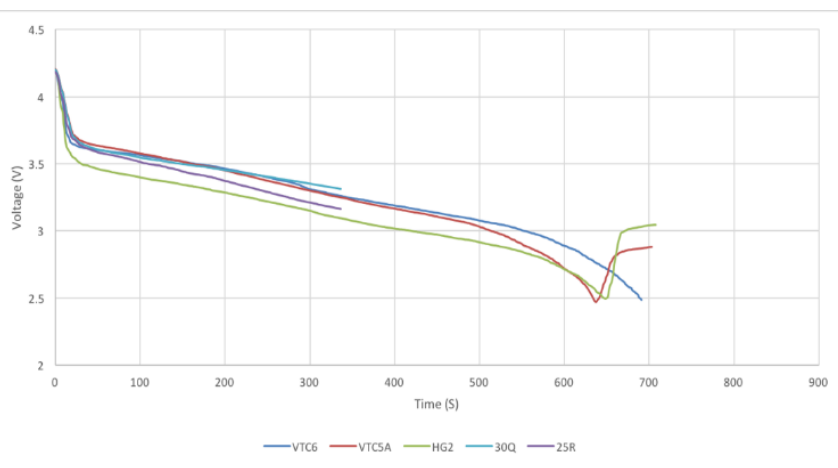

Fig. 2: Single Cell Tests - Voltages from 15A Discharge with No Cooling

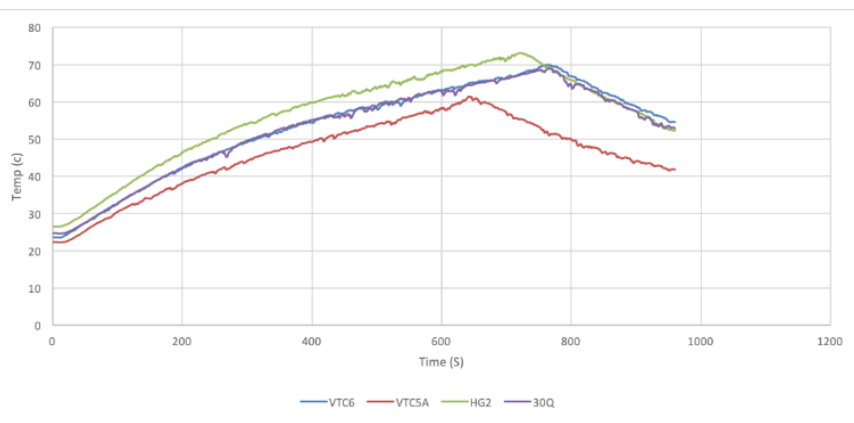

Fig. 3: Single Cell Tests - Temperatures from 15A Discharge with No Cooling

Fig. 2 shows the voltages in the discharge cycle of the five tested cells, and Fig. 3 shows the temperatures monitored against time in seconds. The $30 \mathrm{Q}$ and $25 \mathrm{R}$ tests appear to stop prior to their conclusion, however, this was data corruption issue which is also affected the $25 \mathrm{R}$ thermal trends.

Among the three cells with full measured data sets, the VTC6 lasted the longest correlating to its larger $3000 \mathrm{mAh}$ capacity. Although HG2 claims to have a $3000 \mathrm{mAh}$ capacity, the results indicated that the VTC6 outperformed it. The VTC5A appears to be superior to the VTC6 which is closely matched by the $30 \mathrm{Q}$ cell. Moreover, both the VTC5A and the $30 \mathrm{Q}$ cells have lower Amp-Hour capacities (2500mAh) in comparison to the VTC6.

The results from this test indicates that the VTC6, VTC5A and $30 \mathrm{Q}$ performed better than the HG2 in thermal. 


\section{B. Test 2: 30A discharge current tests with No cooling}

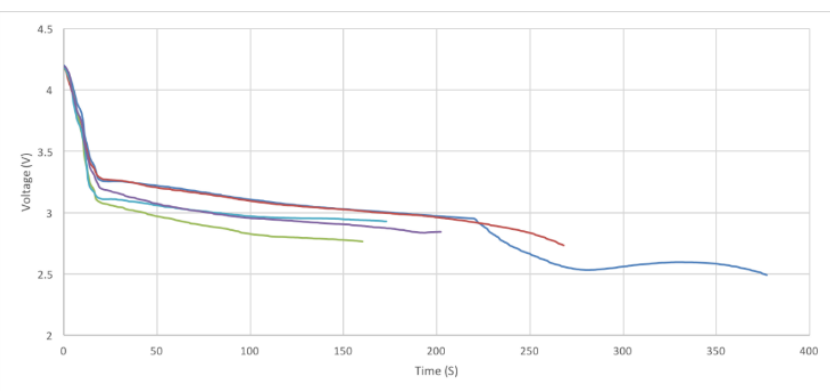

Fig. 4: Single Cell Tests - Voltages from 30A Discharge with No Cooling

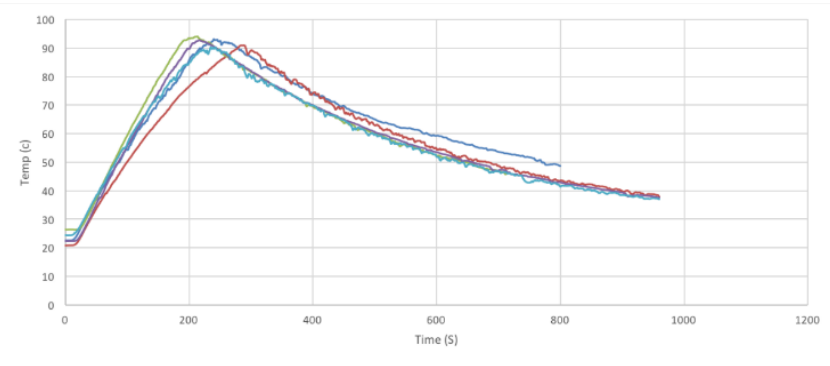

Fig. 5: Single Cell Tests - Temperatures from 30A Discharge with No Cooling

In this test, the VTC5A also out performed other cells in the thermals as shown in Fig. 5. This performance allows the cell to have the longest discharge time before reaching thermal cut-off. Then comes the VTC6. The peak in the voltage curve is from the test continuing after the temperature decreased, which is shown in

Fig. . 4. The 25R and VTC6 performed almost equally well in thermals. However, no cell could fully discharge at $30 \mathrm{~A}$ without reaching thermal cut-off. The thermal characteristic of the VTC5A can be attributed to a low internal resistance which not only decreases the amount of energy heating the cell during discharge but also allows a higher discharge current due to a lower internal voltage drop under load.

\section{Test 3: 15A discharges with active air cooling}

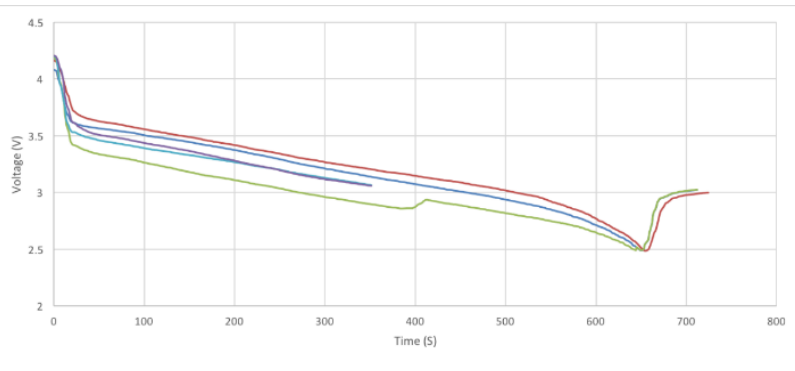

Fig. 6: Single Cell Tests - Voltages from 15A Discharge with Active Air Cooling

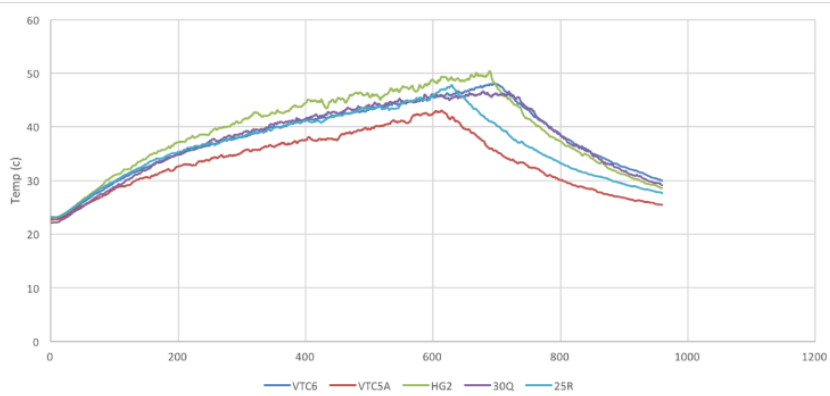

Fig. 7: Single Cell Tests - Temperatures from 15A Discharge with Active Air Cooling

Data corruption affected the voltage curve of the $25 \mathrm{R}$ cell in Fig. . 6. Other than this, all the cells performed very well with the VTC5 and VTC6 performing notably better than the rest (accredited to their low internal resistance shown in the increased voltage under load during the constant gradient region of the discharge).

Compared to the 15A test, without cooling, the cells discharged for a comparable amount of time although the VTC6 didn't last as long. This could be caused by the positive affect of heating of the electrolyte on performance of the cell which is reduced with the cooled cell.

Moreover, the cooling solution worked very well. Fig. . 7 shows that all the cells could complete the discharge with the peak temperatures being between $42^{\circ} \mathrm{C}$ and $51^{\circ} \mathrm{C}$ compared to $61{ }^{\circ} \mathrm{C}$ and $73^{\circ} \mathrm{C}$ during the same test without cooling, a difference of circa to $22^{\circ} \mathrm{C}$.

As seen in previous tests, the VTC5A performed excellently in the thermal tests, with only the HG2 performing significantly worse than the rest.

\section{Test 4:30A discharge current test with active air cooling}

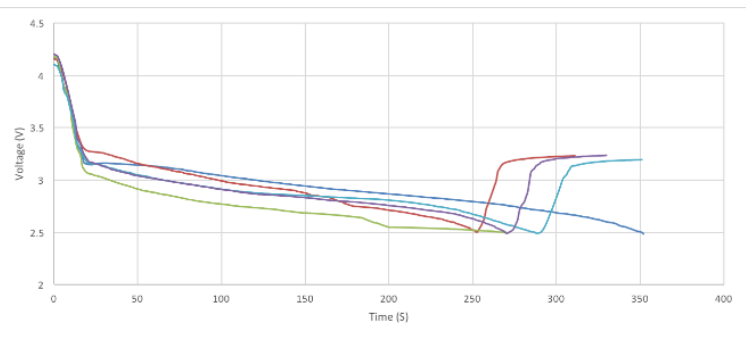

Fig. 8: Single Cell Tests - Voltages from 30A Discharge with Active Air Cooling

This test really differentiates the cells under extreme load and thermal conditions.

Fig. $.8 \& 9$ show the voltages and temperature from the various cells where the VTC6 really excels. The VTC6 takes over 60s longer to complete its discharge due to its higher capacity, which is clearly not impacted too heavily by the maximum load allowed in the MSDS. 


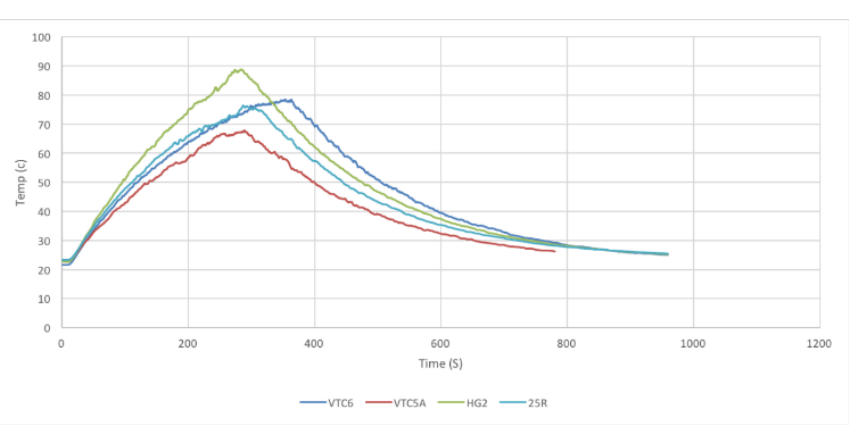

Fig. 9: Single Cell Tests - Temperatures from 30A Discharge with Active

Air Cooling

The VTC5A seems to be the best cell maintaining its low voltage drop until the 50s to 80s mark where the VTC6 takes over and maintains a higher voltage than every other cell until the end of the test. Thermally, the VTC5A outperforms every other cell reaching a peak temperature of $68^{\circ} \mathrm{C}$ and cooling with a similar profile to every other cell. The HG2 performs the worst as seen in other tests. The 25R and VTC6 perform very similarly until the load is removed. The VTC6 increases to a peak of $79^{\circ} \mathrm{C}$.

Overall The cell with the best overall performance, in comparison with the other cells under test, would be the VTC5A as shown in the results above. The heating effect will be amplified when there are hundreds of cells in proximity as the ambient air will not be adequate to cool them, especially under large loads. Fortunately, a very low airflow seems to have a large effect on the cell temperature due to the large temperature difference between the ambient air and cell temperature. A cooling system is required to allow the cell to stay within their permitted operational temperature range. Furthermore, mixing cells from different manufacturer does affect the battery performance especially in cell voltage balancing, current capacity and thermal performance.

Based on all the obtained result the battery cell chosen are VTC6, also the cooling system is a requirement to meet the power requirements, a module configuration of eight parallel cells with four series cells (8P4S) will be used. These modules will be charged to $16 \mathrm{~V}$ (4V per cell) and capable of a $240 \mathrm{~A}$ discharge. When built into the vehicle with 25 modules, the battery configuration will be an $8 \mathrm{P} 100 \mathrm{~S}$ setup. This will have a voltage range from $400 \mathrm{~V}$ (up to $420 \mathrm{~V}$ ) to $250 \mathrm{~V}$ and capable of a $240 \mathrm{~A}$ discharge.

\section{BATTERY MODULE TEST}

The test has been applied to the module as shown in Fig.10, thermocouples used to monitor and record Temperatures around the module. These locations are highlighted in Fig.10, for the high current discharges, the module was connected to a programmable load capable of drawing the full $240 \mathrm{~A}$ from it. However, the safety cut off parameters used are: if the temperature exceed $80^{\circ} \mathrm{C}$ at any location of the pack, or the current draw higher than $240 \mathrm{~A}$, or the cell reach it maximum voltage.

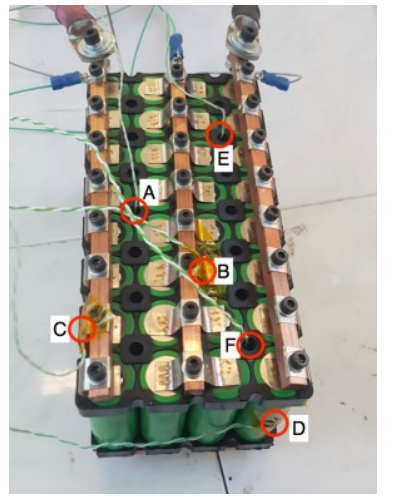

Fig. 10: High voltage Battery Pack

Fig.11, shows the thermals from of the module with a discharge from $16 \mathrm{~V}(4.0 \mathrm{~V}$ per cell) at $240 \mathrm{~A}$, constant current load with three fans pulling air through the module to cool it. The test lasted $127,000 \mathrm{mS}$ with the maximum temperature reached being $75.46^{\circ} \mathrm{C}$ at the first core monitoring point, closely followed by the second core measuring point. The rest of the measuring points are significantly cooler $\left(<50^{\circ} \mathrm{C}\right)$ than the two core measurements. The profile of the temperature curve of the middle interconnect seems bizarre at first inspection. However, a greater understanding of the physical properties and thermal mass of the module explains this shape. When the load is applied to the module, the temperature increases almost linearly, as expected. As soon as the load is removed, current stops passing through the interconnect, so the temperature immediately starts to fall as the thermal energy dissipated in the interconnect becomes zero.After an initial cooling period, the thermal energy in the cells and surrounding module components soak into the interconnect and other cooler parts. This transfer of energy causes the temperatures inside the module to converge before cooling together at the same rate dependant on the ambient air temperature and the airflow through the module.

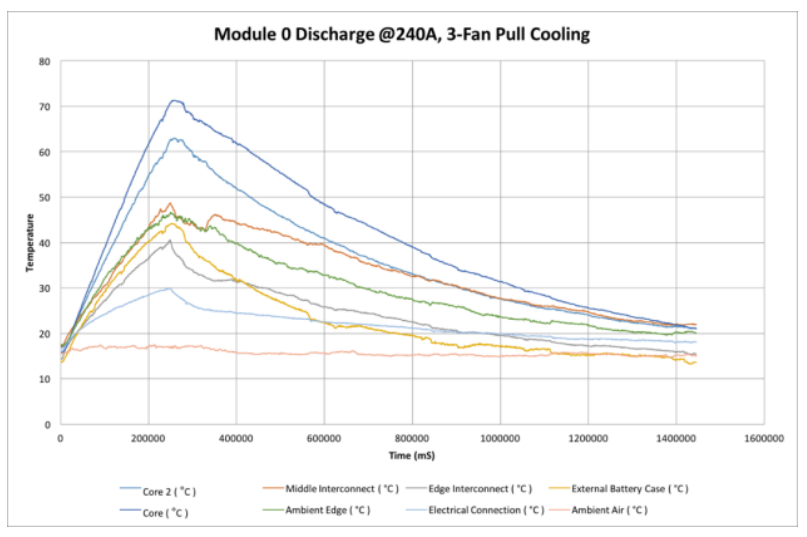

Fig. 11: Module Zero Discharge, 240A 3-Fan Pull Cooling

The second test performed was on the module with a discharge from $16 \mathrm{~V}(4.0 \mathrm{~V}$ per cell $)$ at $240 \mathrm{~A}$ constant 
current load with three fans pulling air through the module and three fans pushing air through the module on the opposite side to cool it. This test was performed with the aim of comparing different cooling configurations and how increased air flow and different fluid dynamics can affect cooling of the module. Fig.12, shows the thermals from this test. The test lasted $140,000 \mathrm{mS}$ with the maximum temperature reached being $73.31^{\circ} \mathrm{C}$ at the first core monitoring point. The rest of the measuring points are significantly cooler $\left(<60^{\circ} \mathrm{C}\right)$ than the core measurement. This test used twice as many cooling fans as the previous test and lasted 13 seconds longer (10.2\% improvement). It is also interesting to observe that aside from the core temperature which caused the thermal cut-off, all the other temperatures are much lower.

Compared to the fist test, the new configuration which provides greater air flow only has one significantly hotter point. This can be explained by understanding how the six fans were pushing and pulling air through the module. The measuring point "Core 2 " is in a position where the addition of air being pushed into the module greatly reduces the heating of this area. This point is also kept cooler as the three fan configuration places a fan in the middle of the module which directly pushes cool ambient air onto the "Core 2" thermocouple. This cooling solution is better at keeping the module cool than both the natural convection cooling and the "3-Fan Pull" configuration tested previously. This solution will be compared to the other solutions later as using six fans to achieve a $10.2 \%$ improvement in discharge time and overall slightly cooler temperatures is not viable due to increased weight, cost and power consumption.

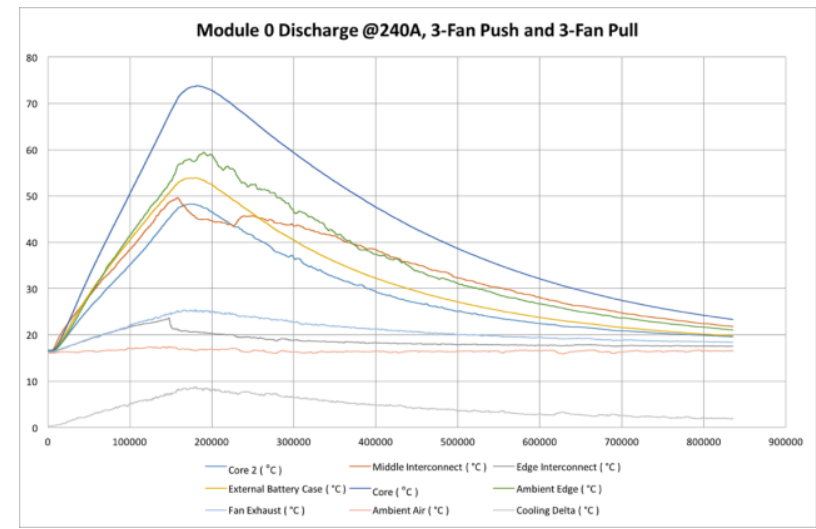

Fig. 12: Module Zero Discharge, 240A 3-Fan Pull and 3-Fan Push Cooling

Fig.13 is a graph comparing the two hottest points of the module during the three-fan push-pull and the three-fan pull tests. The aim of this comparison is to decide which air flow method is more efficient at cooling the pack between these otherwise identical cooling solutions.

As stated previously, the test using the push-pull configuration lasted $10.2 \%$ longer than the test with fans only pulling air through the module. It did this with a maximum temperature of $73.31^{\circ} \mathrm{C}$ compared to the maximum temperature of $75.46^{\circ} \mathrm{C}$ for the pull configuration, $2.9 \%$ cooler.
However, an improvement in run time of $10.2 \%$ and a $2.9 \%$ cooler pack are both significant, the trade-offs for this increased performance are $100 \%$ increase in cooling system weight, $100 \%$ increase in cooling system cost and $100 \%$ increase in cooling system power consumption. Although the improvements would result in a cooler pack and ultimately the ability to run a higher duty cycle, the resulting increase in cooling system requirements are not worth the improvements. Following the conclusion that a pull only cooling system is ultimately better than a push-pull system, the last test performed was on the module with a discharge from $16 \mathrm{~V}(4.0 \mathrm{~V}$ per cell) at $240 \mathrm{~A}$ constant current load with two fans pulling air through the module to cool it. This test was performed to assess the suitability of using two fans as opposed to 3 fans per module, resulting in a $33 \%$ reduction in cooling system requirements.

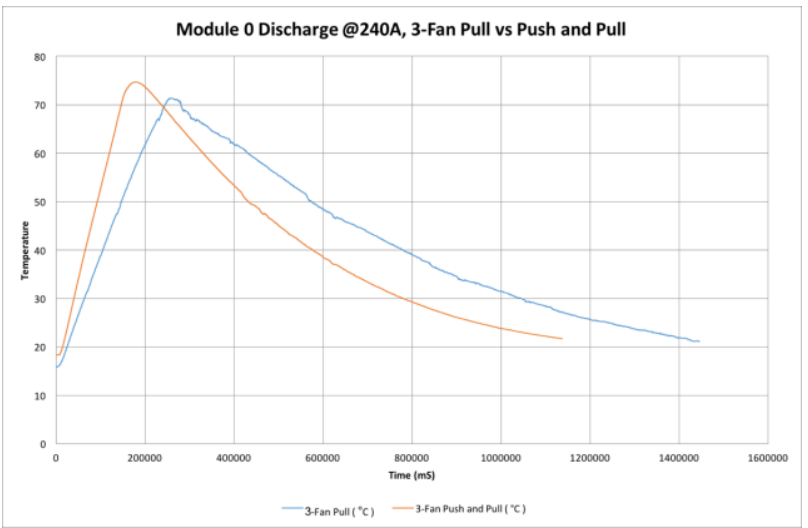

Fig. 13: Module Zero Discharge, 240A 3-Fan Pull Vs 3-Fan Push Cooling

Fig. 14 shows the thermals of two fan pull cooling, the discharge lasted $128,000 \mathrm{mS}$ with the maximum temperature reached being $76.2^{\circ} \mathrm{C}$ at the first core monitoring point, closely followed by the second core measuring point. The rest of the measuring points are significantly cooler $\left(<60^{\circ} \mathrm{C}\right)$ than the two core measurements.

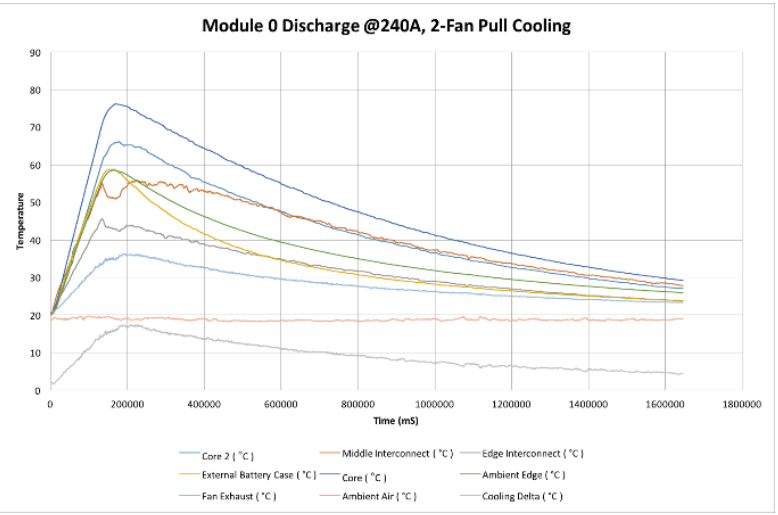

Fig. 14: Module Zero Discharge, 240A 2-Fan Pull Cooling

The following test performed was on the module under same condition to the above, with only a single fan to cool it. 
Fig.15 shows the result from this test. The air flow is not enough to keep the module cool and as a result the discharge only lasted $104,000 \mathrm{mS}$ with a thermal cut off required. Compared to the two-fan pull setup, the cooling delta line is much lower. This shows that the configuration is not removing as much thermal energy from the pack which explains why there are three regions shown on the graph all rapidly increasing temperature, opposed to a single region causing the thermal cut-off witnessed in the other discharges with better cooling. The last two graphs emphasise how useful the cooling delta is as a method of ranking and measuring the performance of the cooling configuration.

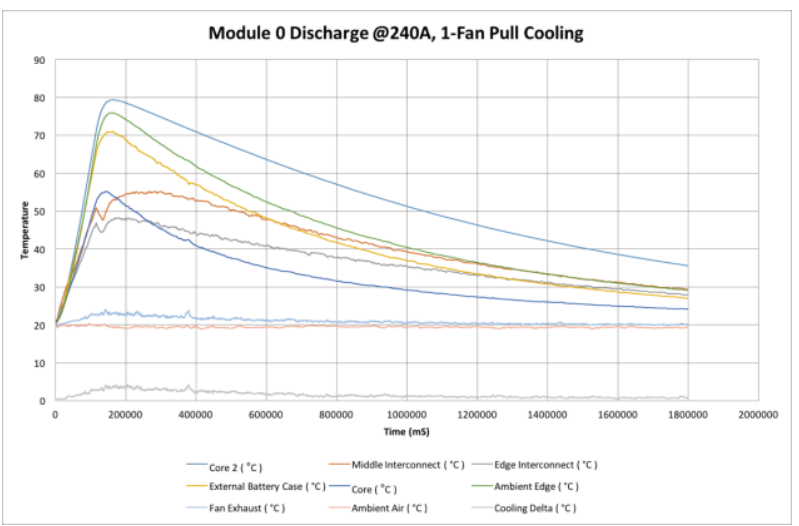

Fig. 15: Module Zero Discharge, 240A 1-Fan Pull Cooling

Overall, The data currently indicates that the two-fan pull setup is the ideal compromise between cooling performance, weight, power consumption and cost. Therefore, this fan configuration was used on the longer $72 \mathrm{~A}$ endurance run to simulate a more realistic race event where the average power consumption would be approximately $28 \mathrm{~kW}$.

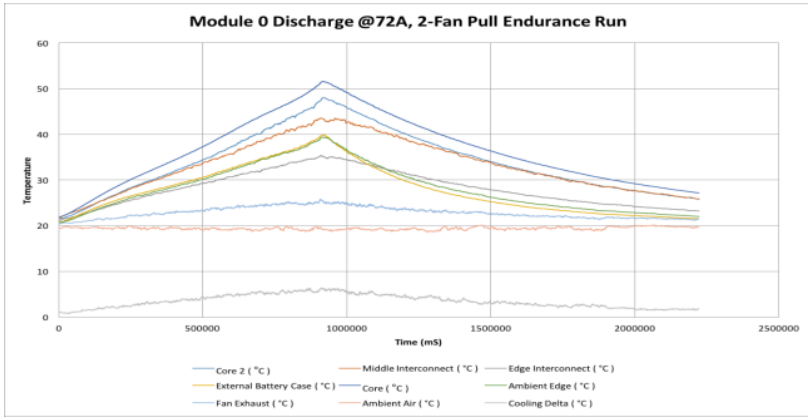

Fig. 16: Module Zero Discharge, 72A 2-Fan Pull Cooling

Fig.16 shows the thermals from this test. The test lasted $916,000 \mathrm{mS}$ with the maximum temperature reached being $51.55^{\circ} \mathrm{C}$ at the first core monitoring point. The only other points to exceed $40^{\circ} \mathrm{C}$ at any point during the discharge are the "Middle Interconnect" and the "Core 2 " measuring points. The e module is fully discharged to $10 \mathrm{~V}(2.5 \mathrm{~V}$ per cell) without reaching thermal cut-off, something which had not been achieved until now. This test also shows that under average load conditions the interconnects (the middle one specifically) heat up a lot more than the shorter high current burst tests performed previously. This is no more than an observation and temperatures are still very reasonable, safe and within competition limits.

Fig. 17 shows two thermal images captured during the $72 \mathrm{~A}$ endurance run. Both photos are near the end of the discharge where the module is thermally saturated and near its maximum temperature.

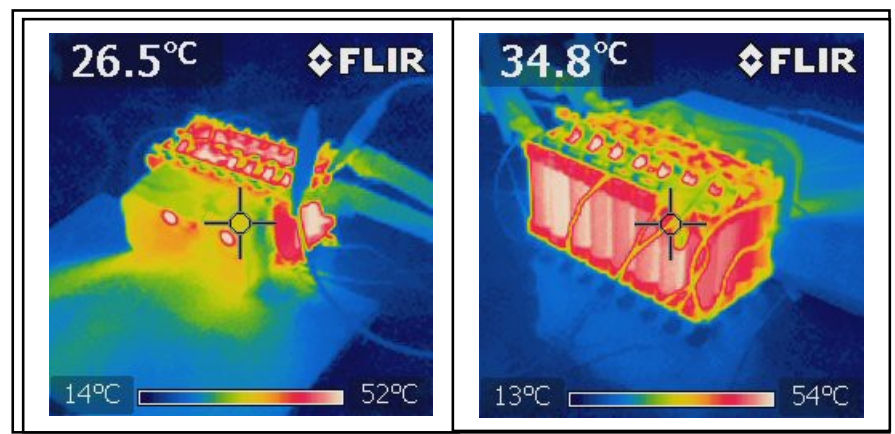

Fig. 17: A thermal Image at the frant $\&$ rear of Module Zero 72ADicharge

\section{CONCLUSION}

This paper presented a comparative analysis of lithium battery cells used as a pack for electrical race car, from different manufacturer, the best performance cells has been used to build a battery pack as specified for racing car in SAE formula, the celles are connected in series and parallel to achieve the voltage and the power requirement for the racing car. An forced air-cooling system is a signeficatly important to the battery pack has been investigated in order to keep the cells temperature in the operating range.

\section{REFERENCES}

[1] European Commission. (2011, February 28). Mobility \& Transport. Retrieved March 26, 2018, from European Commission: http://ec.europa.eu/transport/urban/vehicles/road/electric_en.htm

[2] Markowitz, M. 2013, February 22. Wells to wheels: electric car efficiency. Retrieved March 26, 2018, from Energy Matters: https://matter2energy.wordpress.com/2013/02/22/wells-towheelselectric-car-efficiency/

[3] BU-205: Types of Lithium-ion. Retrieved March 26, 2018, from Battery university: http://batteryuniversity.com/learn/article/types_of_lithium_ion

[4] Y Kim and N Aehyuck Ch Ang. Design and management of energyefficient hybrid electrical energy storage systems. Springer International Publishing, 2014.

[5] K Sehil, A super-capacitor-based energy storage for quick variation in stand-alone PV systems. PhD thesis from Brunel University 2018.

[6] M. Perrin, P. Malbranche, F. Mattera, L. Simonin, D. U. Sauer, P. Lailler, A. Joessen, B. Willer, M. Dahlen, A. Ruddell, I. Cyphelly, N. Tassin, and M. Bruesewitz. Evaluation and perspectives of storage technologies for pv electricity. In 3rd World Conference on Photovoltaic Energy Conversion, 2003. Proceedings of, volume 3, pages 2194-2197 Vol.3, May 2003.

[7] C. Glaize and S. Genies. Lithium batteries and other electrochemical storage systems. John Wiley \& Sons, 2013.

[8] Formula SAE rules, https://www.fsaeonline.com/content/201718\%20FSAE\%20Rules\%20PRELIMINARY.pdf，2017-2018 formula SAE Rules.Fsaeonline.com. 2020. [Accessed 30 June 2020]. 